\title{
Effect of Dietary Protein Level and Origin on the Redox Status in the Digestive Tract of Mice
}

\author{
Chunmei Gu ${ }^{1}$, Yonghui Shi ${ }^{1,2}$ and Guowei Le ${ }^{1,2, *}$ \\ 1 State Key Laboratory of Food Science and Technology, Jiangnan University, Wuxi, Jiangsu \\ 214122, P. R. China \\ 2 Research Institute of Food Nutrition and Safety, School of Food Science and Technology, \\ Jiangnan University, Wuxi, Jiangsu 214122, P. R. China \\ * Author to whom correspondence should be addressed; E-mail: jjnong2008@jlau.edu.cn; \\ Tel. +86-510-85917789; Fax: +86-510-85917789
}

Received: 6 November 2008; in revised form: 11 March 2008 / Accepted: 14 March 2008 /

Published: 2 April 2008

\begin{abstract}
The present study was undertaken to evaluate the effects of high protein (soybean protein or casein) on the balance between production of free radicals and antioxidant level in digestive organs of mice. For this purpose, male (C57BL/6J) mice were adapted to experimental diets containing soybean protein or casein with $20 \%$ (normal protein diets, NPDs) or $60 \%$ (high protein diets, HPDs), and HPDs supplemented with $0.06 \mathrm{~g} / \mathrm{kg}$ cysteamine. After two weeks of feeding, oxidative and antioxidative parameters in duodenum, liver and pancreas were measured. The results show that ingestion of high protein markedly increased contents of superoxide anion and malondialdehyde (MDA), decreased activities of superoxide dismutase (SOD), glutathione peroxidase (GSH-Px), catalase (CAT) and $\mathrm{Na}^{+} \mathrm{K}^{+}$-ATPase, and content of reduced glutathione (GSH) in digestive organs of mice $(\mathrm{P}<0.05)$. Levels of oxidative parameters were lower and antioxidant capacity of both enzyme and non-enzyme was higher in mice fed with soybean protein than those fed with casein. In groups fed HPDs supplemented with cysteamine, oxidative stress was mitigated. However, oxidative parameter levels were still higher than those of NPD-fed groups. The present study indicates that ingestion of high protein diets could result in an imbalance between oxidant and antioxidant, and thus induce oxidative stress in digestive organs of mice. The oxidative damage was smaller in mice fed with high level of soy protein in comparison with casein.
\end{abstract}

Keywords: High protein diet, Oxidative stress, Soybean protein, Digestive organs, Mice. 


\section{Introduction}

The scientific literature on whether ingestion of high protein can cause adverse effects to the healthy population is controversial. High protein diets are suspected to be detrimental to the renal and hepatic functions, calcium balance and insulin sensitivity, such as increased urinary nitrogen excretion, glomerular filtration rate, kidney hypertrophy, renal hemodynamics and eicosanoid production in renal tubules [1-3]. In addition, increased risk of renal cell cancer [4] and a higher incidence of noninsulin-dependent diabetes (NIDDM) [5,6] have been linked to high-protein intake. Furthermore, Vlajinac et al. [7] and Holmes et al. [8] found a relationship between high-protein intake and prostate cancer and calcium oxalate nephrolithiasis. High protein ingestion increases amino acid oxidation and urea synthesis [9] and decreases the nutritional efficiency of energy utilization [10,11]. However, the reoxidation of reducing equivalents derived from amino acid oxidation is linked to the mitochondrial redox chain [12]. Free radical generation during mitochondrial oxygen reduction may lead to oxidative stress if the antioxidant capacity is insufficient to quench the extra free radical production. Thus, intake of high protein may cause a situation of physiological oxidative stress.

It was reported that dietary-protein origin may influence cholesterol metabolism. Soybean protein, for example, as compared with casein, lowers plasma cholesterol concentrations in rats [13], exhibits anticarcinogenic effects [14], and regulates polyunsaturated fatty acid metabolism $[15,16]$. In addition, many findings showed that soybean protein had antioxidative activity. Madani et al. [17] reported that rats fed a soybean protein diet were found to have lower concentrations of plasma thiobarbituric acid-reactive substances (TBARS) than rats fed a casein diet. Soybean protein intake has been reported to inhibit oxidative modification of LDL in vitro [18]. Furthermore, Aoki et al. [19] found that intake of soybean protein may reduce paraquat-induced oxidative stress in rats. The present study was designed to investigate whether high protein (soybean protein or casein) could increase generation of free radicals and decrease antioxidant capacity in digestive organs of mice, and the effect of protein origin on the balance between oxidative levels and antioxidative abilities.

\section{Materials and Methods}

\subsection{Animals and diets}

The care and use of the mice followed the institutional guideline of Jiangnan University. Male C57BL/6J mice (body weigh, 12-13 g; 3 wk old) were used in this study. All animals were housed under a controlled atmosphere (temperature, $23^{\circ} \mathrm{C} \pm 1$; relative humidity, $55 \pm 5 \%$; and a fixed 12-h light: dark cycle, light 0700 to $1900 \mathrm{~h}$ ). Prior to the feeding experiment they were allowed free access to deionized water and a semipurified diet (Shanghai, China; crude protein $180 \mathrm{~g} / \mathrm{kg}$, crude fat $40 \mathrm{~g} / \mathrm{kg}$, metabolizable energy $11.9 \mathrm{MJ} / \mathrm{kg}$ ) for 10 days to allow acclimatization to these conditions. Then all animals were divided randomly into six groups of ten each. Group 1 and 4 (normal protein diets, NPD) received a normal diet containing 20\% casein or soy protein, respectively. Group 2 and 5 (high protein diets, HPD) received a high protein diet containing $60 \%$ casein or soy protein, respectively. Group 3 and 6 received HPDs supplemented with $0.06 \mathrm{~g} / \mathrm{kg}$ cysteamine. Casein and soy protein was exchanged isoenergetically by corn starch. The composition of the experimental diets is shown in Table 1. All 
mice were allowed free access to the experimental diets and deionized water throughout the experimental period.

Table 1. Composition of diets ${ }^{\mathrm{a}}$.

\begin{tabular}{l|lll|lll}
\hline \multirow{2}{*}{ Ingredient } & \multicolumn{4}{|c|}{ Casein (g/kg diet) } & \multicolumn{3}{c}{ Soybean protein (g/kg diet) } \\
& Group1 & Group2 & Group3 & Group4 & Group5 & Group6 \\
\hline Casein $^{\mathrm{b}}$ & 200 & 600 & 600 & & & \\
soybean protein $^{\mathrm{b}}$ & & & & 200 & 600 & 600 \\
Corn starch $^{\mathrm{c}}$ & 580 & 220 & 220 & 580 & 220 & 220 \\
Sucrose & 60 & 20 & 20 & 60 & 20 & 20 \\
Soybean oil $^{\mathrm{d}}$ & 50 & 50 & 50 & 50 & 50 & 50 \\
Cellulose powder $^{\mathrm{a}}$ & 50 & 50 & 50 & 50 & 50 & 50 \\
Mineral mixture $^{\mathrm{e}}$ & 40 & 40 & 40 & 40 & 40 & 40 \\
Vitamin mixture $^{\mathrm{f}}$ & 20 & 20 & 20 & 20 & 20 & 20 \\
Cysteamine $^{\mathrm{c}}$ & & & 0.06 & & & 0.06 \\
\hline
\end{tabular}

(a) The diets were semipurified, isoenergetic (16.20 MJ/kg); (b) Shanghai, China; (c) Wuxi, China; (d) The commercial product $(50 \mathrm{~g} / \mathrm{kg}$ ) provides $11.81 \%$ of energy. The soybean oil provides the following fatty acids: $14: 0$, traces; C16:0, 10.3; $\mathrm{C} 16: 1 \omega-7,0.1$; C18:0, 3.9; C18:1 $\omega-7+\omega-9,22.1 ; \mathrm{C} 18: 2 \omega-6,54.8 ; \mathrm{C} 18: 3 \omega-3,7.5 ; \mathrm{C} 20: 0,0.4 ; \mathrm{C} 20: 1$ $\omega-9+\omega-11,0.2 ; \mathrm{C} 22: 0,0.4 ; \mathrm{C} 22: 5 \omega-3$, traces; C24:0, traces; sum of saturated fatty acids (S), 15; sum of monounsaturated, 22.4; sum of polyunsaturated fatty acids (P), 84.7; $\mathrm{P} / \mathrm{S}, 5.65 ; \Sigma \omega-6 / \Sigma \omega-3,7.3$; (e) The salt mixture provides the following amounts $\left(\mathrm{g} / \mathrm{kg} \operatorname{diet}^{-1}\right)$ : Ca, $4 ; \mathrm{K}, 2.4 ; \mathrm{Na}, 1.6 ; \mathrm{Mg}, 0.4 ; \mathrm{Fe}, 0.12$; trace elements: $\mathrm{Mn}, 0.032 ; \mathrm{Cu}$, $0.005 ; \mathrm{Zn}, 0.018$; Co, 0.00004; I, 0.00002; (f) The vitamin mixture provides the following amounts $\left(\mathrm{mg} / \mathrm{kg} \operatorname{diet}^{-1}\right)$ : retinol, 12; cholecalciferol, 0.125; thiamin, 40; riboflavin, 30; pantothenic acid, 140; pyridoxine, 20; inositol, 300; cyanocobalamine, 0.1; ascorbic acid, 1600; (dL) $\alpha$-tocopherol, 340; menadione, 80; nicotinic acid, 200; paraaminobenzoic acid, 100; folic acid, 10; biotin, 0.6; choline, 2720. Group 1and 4 (normal protein diets [NPD]), a normal diet containing $20 \%$ casein or soy protein, respectively; Group 2 and 5 (high protein diets [HPD]), a high protein diet containing $60 \%$ casein or soy protein, respectively; Group 3 and 6 , high protein diets plus $0.06 \mathrm{~g} / \mathrm{kg}$ cysteamine.

\subsection{Sampling procedures}

At the end of the experimental period, mice were deprived of food overnight but had free access to deionized water. Mice were sacrificed by decapitation and the whole duodenum, liver and pancreas were removed immediately, gently rinsed in ice-cold PBS and then were cut into 50- to 100-mg portions as tissue samples. They were frozen in liquid nitrogen and stored at $-80^{\circ} \mathrm{C}$ for further treatment. After thawed, tissue samples were homogenized with ice-cold $0.9 \% \mathrm{NaCl}$ solution and then were centrifuged at $4000 \mathrm{~g}$ for $15 \mathrm{~min}$ at $4{ }^{\circ} \mathrm{C}$. The supernates were used to determined protein content and antioxidant defense and lipid peroxidation. 


\subsection{Analytical methods}

\subsubsection{Superoxide anion determination}

The level of oxidative stress was determined by specifically measuring superoxide anion, as described by Pick [20].

\subsubsection{Lipid peroxidation determination}

Lipid peroxidation products, thiobarbituric acid reactive substances (TBARS), were measured by a standard method and are expressed as the content of malondialdehyde (MDA) in nanomoles per milligram of protein [21].

\subsubsection{Glutathione peroxidase assay}

Glutathione peroxidase (GSH-Px) activity was measured according to the method of Hafeman et al. [22]. One unit of GSH-Px was defined as a decrease in the log of mmol GSH per minute and was expressed in unit per milligram protein. The automatically decrease of GSH without enzyme (control reaction under same condition) was subtracted from calculation.

\subsubsection{Superoxide dismutase assay}

Total superoxide dismutase (SOD) activity was assayed using hypoxanthine-xanthine oxidase-generated $\mathrm{O}_{2}^{-}$to reduce nitrotetrazolium (NBT) monitored spectrophotometrically at $550 \mathrm{~nm}$. Inhibition of NBT reduction to $50 \%$ of maximal is defined as $1 \mathrm{U}$ of SOD activity and enzyme activity was expressed in units per milligram protein [23].

\subsubsection{GSH assay}

Reduced glutathione (GSH) was measured by the procedure of Moron et al. [24]. In this procedure, reduced GSH reacts with 5,5-dithiobis-(2-nitrobenzoic acid) to produce a compound that absorbs at $412 \mathrm{~nm}$.

\subsection{6 $\mathrm{Na}^{+} \mathrm{K}^{+}$-ATPase and catalase activity determination}

$\mathrm{Na}^{+} \mathrm{K}^{+}$-ATPase and catalase (CAT) activities in digestive organs were determined by Reinila et al. [25] and Aebi [26], respectively, using commercial kits from Nanjing Jiancheng Bioengineering Institute. The protein content was determined using the method of Lowry et al. [27]. 


\subsection{Statistical analysis}

Data are reported as means $\pm \mathrm{SD}, n=10$. Differences between mean values were determined by ANOVA followed by comparisons using the Newman-Keuls multiple range test. Differences with $P<$ 0.05 were considered significant.

\section{Results}

\subsection{Superoxide anion content in duodenum, liver and pancreas of mice}

Figures 1 to 3 show the effect of high protein on superoxide anion content of soybean protein or casein-fed groups. There was a significant increase $(\mathrm{P}<0.05)$ in superoxide anion content in duodenum, liver and pancreas of HPD-fed mice. Superoxide anion content was strikingly lower in duodenum and liver of mice fed soybean protein than those fed casein. Treatment with cysteamine ameliorated the change induced by HPD feeding.

Figure 1. Superoxide anion content in duodenum of mice. Bars represent means \pm SD. Means not sharing the same letter are significantly different within experimental period $(P<0.05, n=10)$. NPD, a normal diet containing $20 \%$ casein or soy protein; HPD, a high protein diet containing $60 \%$ casein or soy protein; HPD + CYS, high protein diets plus $0.06 \mathrm{~g} / \mathrm{kg}$ cysteamine.

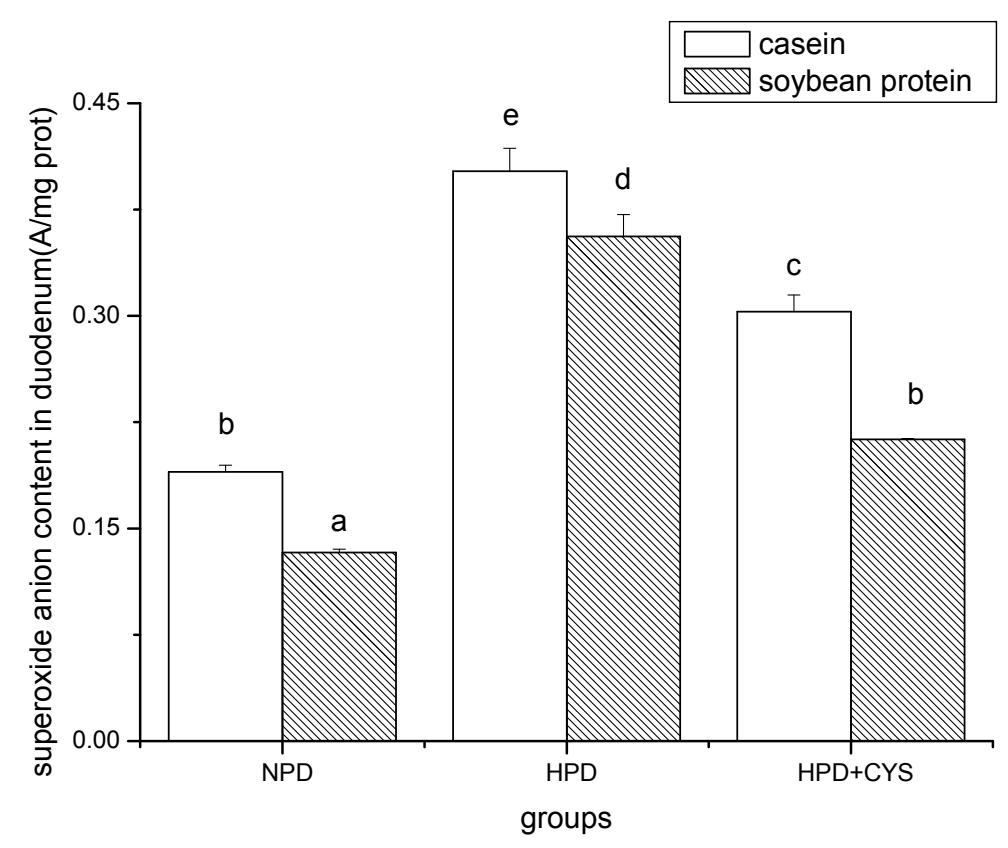


Figure 2. Superoxide anion content in liver of mice. Bars represent means \pm SD. Means not sharing the same letter are significantly different within experimental period $(P<0.05$, $n=10$ ). NPD, a normal diet containing $20 \%$ casein or soy protein; HPD, a high protein diet containing $60 \%$ casein or soy protein; HPD + CYS, high protein diets plus $0.06 \mathrm{~g} / \mathrm{kg}$ cysteamine.

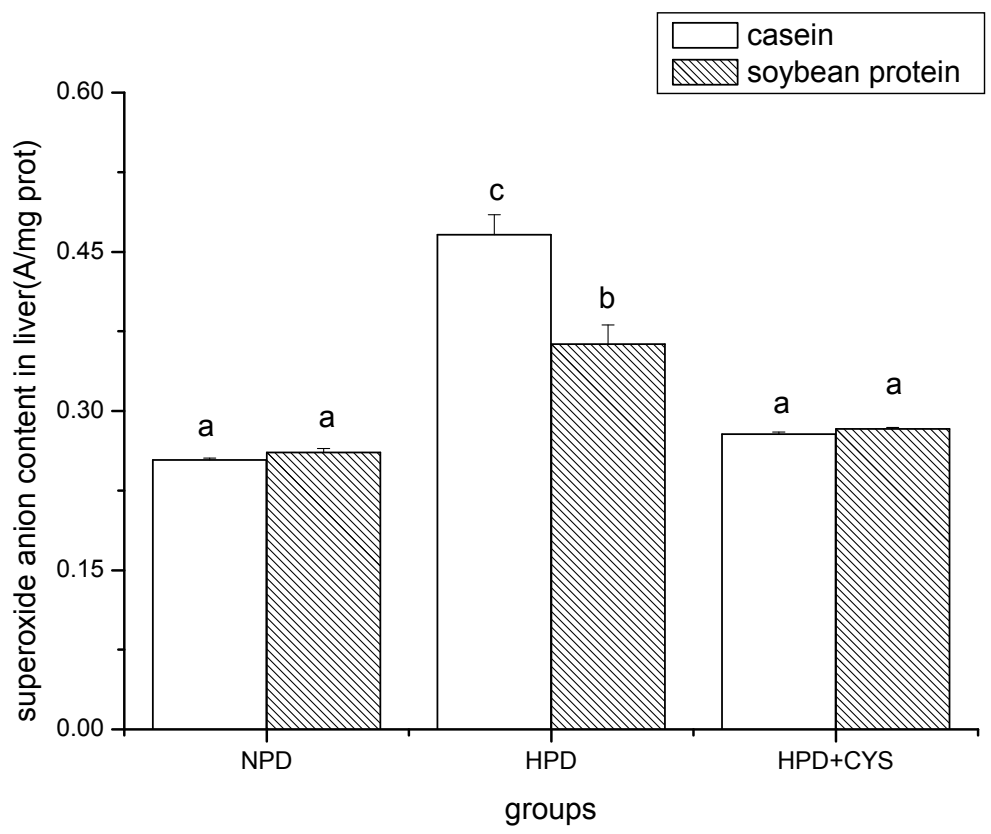

Figure 3. Superoxide anion content in pancreas of mice. Bars represent means \pm SD. Means not sharing the same letter are significantly different within experimental week $(P<0.05, n=10)$. NPD, a normal diet containing $20 \%$ casein or soy protein; HPD, a high protein diet containing $60 \%$ casein or soy protein; HPD + CYS, high protein diets plus $0.06 \mathrm{~g} / \mathrm{kg}$ cysteamine.

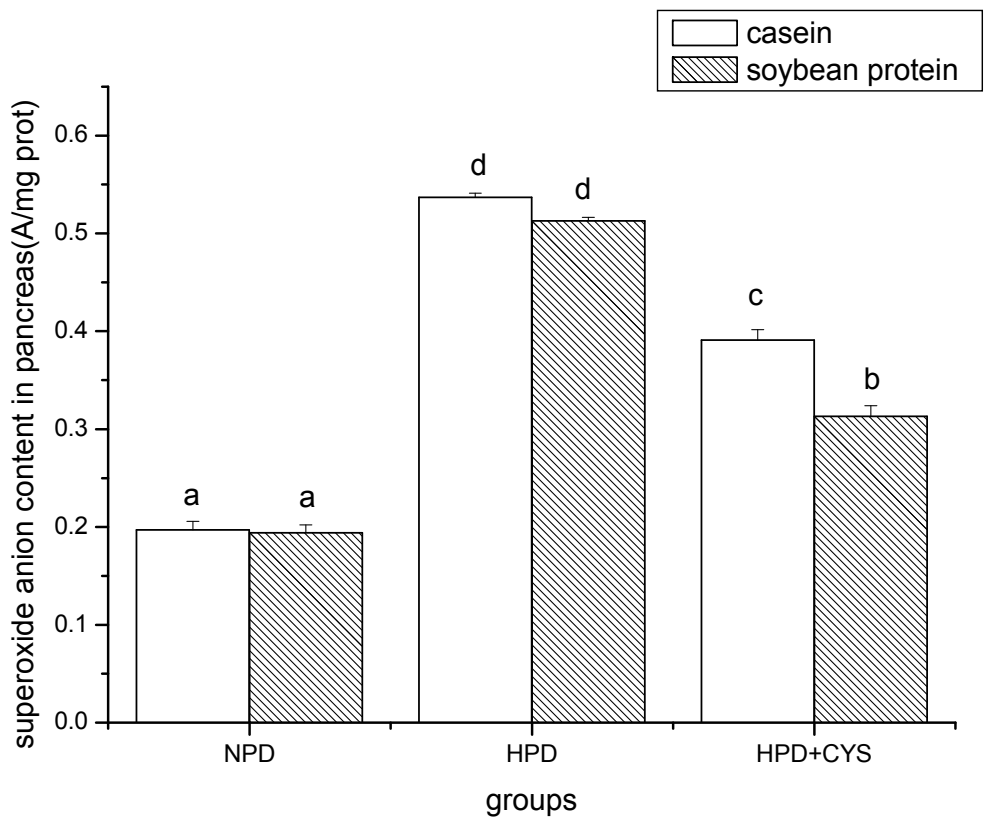




\subsection{MDA contents and SOD activities in duodenum, liver and pancreas of mice}

Feeding of the HPDs for $14 \mathrm{~d}$ resulted in the development of oxidative stress in experimental mice, as is evident from Table 2. There was a significant $(\mathrm{P}<0.05)$ increase in MDA content $(78 \%$ and $104 \%$, $103 \%$ and $75 \%, 138 \%$ and $150 \%$, respectively), whereas lower SOD activity (35\% and $29 \%, 28 \%$ and $18 \%, 31 \%$ and $30 \%$, respectively) in duodenum, liver and pancreas of mice fed casein and soybean protein. However, the level of oxidative parameter was lower, and antioxidant activity was higher in groups fed soybean protein diets compared with those fed casein diets. These abnormalities caused by HPDs were considerably reduced on treatment with cysteamine.

Table 2. MDA contents and SOD activities in duodenum, liver and pancreas of mice.

\begin{tabular}{l|lll|lll}
\hline \multirow{2}{*}{ Groups } & \multicolumn{3}{|c}{ MDA(nmol/mg prot) } & \multicolumn{3}{c}{ SOD(U/mg prot) } \\
& Duodenum & Liver & Pancreas & Duodenum & Liver & Pancreas \\
\hline Group1 & $2.67 \pm 0.12^{\mathrm{ab}}$ & $3.91 \pm 0.26^{\mathrm{a}}$ & $2.09 \pm 0.10^{\mathrm{a}}$ & $95.04 \pm 3.57^{\mathrm{de}}$ & $218.55 \pm 8.25^{\mathrm{c}}$ & $98.92 \pm 2.51^{\mathrm{c}}$ \\
Group2 & $4.76 \pm 0.26^{\mathrm{d}}$ & $7.92 \pm 0.16^{\mathrm{c}}$ & $4.99 \pm 0.12^{\mathrm{c}}$ & $61.27 \pm 4.23^{\mathrm{a}}$ & $158.28 \pm 4.73^{\mathrm{a}}$ & $68.74 \pm 0.50^{\mathrm{a}}$ \\
Group3 & $3.69 \pm 0.15^{\mathrm{c}}$ & $5.84 \pm 0.16^{\mathrm{b}}$ & $3.36 \pm 0.14^{\mathrm{b}}$ & $79.66 \pm 2.36^{\mathrm{bc}}$ & $185.09 \pm 4.82^{\mathrm{b}}$ & $82.60 \pm 1.69^{\mathrm{b}}$ \\
Group4 & $2.28 \pm 0.13^{\mathrm{a}}$ & $4.44 \pm 0.41^{\mathrm{a}}$ & $1.82 \pm 0.09^{\mathrm{a}}$ & $98.35 \pm 3.46^{\mathrm{e}}$ & $204.33 \pm 8.83^{\mathrm{c}}$ & $101.44 \pm 1.78^{\mathrm{c}}$ \\
Group5 & $4.66 \pm 0.35^{\mathrm{d}}$ & $7.77 \pm 0.25^{\mathrm{c}}$ & $4.55 \pm 0.22^{\mathrm{c}}$ & $69.50 \pm 3.02^{\mathrm{ab}}$ & $166.96 \pm 3.48^{\mathrm{ab}}$ & $70.92 \pm 4.05^{\mathrm{a}}$ \\
Group6 & $3.17 \pm 0.26^{\mathrm{bc}}$ & $5.85 \pm 0.07^{\mathrm{b}}$ & $3.09 \pm 0.34^{\mathrm{b}}$ & $84.21 \pm 5.41^{\mathrm{cd}}$ & $182.67 \pm 2.61^{\mathrm{b}}$ & $85.77 \pm 4.34^{\mathrm{b}}$ \\
\hline
\end{tabular}

Values are means $\pm \mathrm{SD}, n=10$. Within an array, values without a common superscript significantly differ, $P<0.05$. MDA, malondialdehyde; SOD, superoxide dismutase; Group 1and 4 (normal protein diets [NPD]), a normal diet containing 20\% casein or soy protein, respectively; Group 2 and 5 (high protein diets [HPD]), a high protein diet containing $60 \%$ casein or soy protein, respectively; Group 3 and 6 , high protein diets plus $0.06 \mathrm{~g} / \mathrm{kg}$ cysteamine.

\subsection{GSH-Px activities and GSH contents in duodenum, liver and pancreas of mice}

The HPD-fed groups exhibited strikingly lower activity of GSH-Px and GSH content in digestive organs compared to the NPD-fed groups (Table 3). Levels of antioxidant parameters were higher in soybean protein groups than casein groups. The HPD and treatment with cysteamine groups exhibited a similar GSH-Px activity except for duodenum. GSH contents were significantly lower in the HPD groups than in the treatment with cysteamine groups.

\subsection{CAT and $\mathrm{Na}^{+} \mathrm{K}^{+}$-ATPase activities in duodenum, liver and pancreas of mice}

Table 4 presents the effects of high levels of soybean protein and casein on CAT and $\mathrm{Na}^{+} \mathrm{K}^{+}$-ATPase activities. There was significant decrease $(\mathrm{P}<0.05)$ in CAT and $\mathrm{Na}^{+} \mathrm{K}^{+}$-ATPase activities of HPD-fed mice compared with NPD-fed mice. CAT and $\mathrm{Na}^{+} \mathrm{K}^{+}$-ATPase activities were higher in soybean protein-fed mice than casein-fed ones. Supplement with cysteamine increased significantly in CAT and $\mathrm{Na}^{+} \mathrm{K}^{+}$-ATPase activities of HPD-fed mice. 
Table 3. GSH-Px activities and GSH contents in duodenum, liver and pancreas of mice.

\begin{tabular}{c|ccc|ccc}
\hline \multirow{2}{*}{ Group } & \multicolumn{3}{|c|}{ GSH-Px(U/mg prot) } & \multicolumn{3}{c}{ GSH(mg/g prot) } \\
& Duodenum & Liver & Pancreas & Duodenum & Liver & Pancreas \\
\hline Group1 & $80.828 \pm 0.925^{\mathrm{e}}$ & $59.963 \pm 0.206^{\mathrm{c}}$ & $102.196 \pm 3.630^{\mathrm{b}}$ & $99.22 \pm 0.32^{\mathrm{d}}$ & $191.29 \pm 4.25^{\mathrm{c}}$ & $153.02 \pm 4.69^{\mathrm{c}}$ \\
Group2 & $58.748 \pm 1.073^{\mathrm{a}}$ & $50.688 \pm 2.038^{\mathrm{a}}$ & $88.169 \pm 4.244^{\mathrm{a}}$ & $38.91 \pm 2.02^{\mathrm{a}}$ & $78.23 \pm 1.93^{\mathrm{a}}$ & $123.38 \pm 2.19^{\mathrm{a}}$ \\
Group3 & $70.476 \pm 1.497^{\mathrm{c}}$ & $53.818 \pm 0.306^{\mathrm{ab}}$ & $97.560 \pm 5.194^{\mathrm{ab}}$ & $65.59 \pm 1.65^{\mathrm{b}}$ & $100.84 \pm 1.47^{\mathrm{b}}$ & $138.97 \pm 2.23^{\mathrm{b}}$ \\
Group4 & $82.610 \pm 0.324^{\mathrm{e}}$ & $61.197 \pm 2.009^{\mathrm{c}}$ & $100.362 \pm 1.224^{\mathrm{b}}$ & $116.27 \pm 3.98^{\mathrm{e}}$ & $184.34 \pm 6.07^{\mathrm{c}}$ & $165.78 \pm 3.09^{\mathrm{d}}$ \\
Group5 & $67.190 \pm 0.573^{\mathrm{b}}$ & $52.718 \pm 0.297^{\mathrm{ab}}$ & $91.768 \pm 2.533^{\mathrm{ab}}$ & $44.31 \pm 1.58^{\mathrm{a}}$ & $84.61 \pm 3.23^{\mathrm{a}}$ & $130.29 \pm 1.73^{\mathrm{a}}$ \\
Group6 & $76.610 \pm 0.566^{\mathrm{d}}$ & $54.930 \pm 0.248^{\mathrm{b}}$ & $97.689 \pm 1.692^{\mathrm{ab}}$ & $78.72 \pm 6.80^{\mathrm{c}}$ & $97.55 \pm 4.62^{\mathrm{b}}$ & $146.11 \pm 1.33^{\mathrm{bc}}$ \\
\hline
\end{tabular}

Values are means $\pm \mathrm{SD}, n=10$. Within an array, values without a common superscript significantly differ, $P<$ 0.05. GSH-Px, glutathione peroxidase; GSH, reduced glutathione; Group land 4 (normal protein diets [NPD]), a normal diet containing 20\% casein or soy protein, respectively; Group 2 and 5 (high protein diets [HPD]), a high protein diet containing $60 \%$ casein or soy protein, respectively; Group 3 and 6 , high protein diets plus $0.06 \mathrm{~g} / \mathrm{kg}$ cysteamine.

Table 4. CAT and $\mathrm{Na}^{+} \mathrm{K}^{+}$-ATPase activities in duodenum, liver and pancreas of mice.

\begin{tabular}{c|ccc|ccc}
\hline \multirow{2}{*}{ Groups } & \multicolumn{3}{|c|}{ CAT(U/mg prot) } & \multicolumn{2}{c}{ Na $^{+} \mathbf{K}^{+}$-ATPase( $\mu$ molPi/mg prot/hour) } \\
& Duodenum & Liver & Pancreas & Duodenum & Liver & Pancreas \\
\hline Group1 & $56.17 \pm 0.75^{\mathrm{e}}$ & $82.16 \pm 0.21^{\mathrm{d}}$ & $78.65 \pm 0.51^{\mathrm{c}}$ & $21.53 \pm 0.32^{\mathrm{d}}$ & $10.67 \pm 0.07^{\mathrm{c}}$ & $3.14 \pm 0.29^{\mathrm{c}}$ \\
Group2 & $25.08 \pm 1.10^{\mathrm{a}}$ & $54.00 \pm 0.58^{\mathrm{a}}$ & $56.54 \pm 1.65^{\mathrm{a}}$ & $13.92 \pm 0.21^{\mathrm{a}}$ & $1.95 \pm 0.23^{\mathrm{a}}$ & $0.95 \pm 0.01^{\mathrm{a}}$ \\
Group3 & $42.44 \pm 1.33^{\mathrm{c}}$ & $73.13 \pm 1.46^{\mathrm{c}}$ & $68.32 \pm 0.66^{\mathrm{b}}$ & $15.97 \pm 0.23^{\mathrm{bc}}$ & $5.47 \pm 0.14^{\mathrm{b}}$ & $1.93 \pm 0.02^{\mathrm{b}}$ \\
Group4 & $57.77 \pm 0.85^{\mathrm{e}}$ & $82.13 \pm 1.48^{\mathrm{d}}$ & $78.88 \pm 0.35^{\mathrm{c}}$ & $22.53 \pm 1.02^{\mathrm{d}}$ & $10.40 \pm 0.18^{\mathrm{c}}$ & $3.72 \pm 0.44^{\mathrm{c}}$ \\
Group5 & $37.54 \pm 1.91^{\mathrm{b}}$ & $58.98 \pm 0.69^{\mathrm{b}}$ & $57.16 \pm 2.94^{\mathrm{a}}$ & $14.79 \pm 0.64^{\mathrm{ab}}$ & $2.59 \pm 0.51^{\mathrm{a}}$ & $0.99 \pm 0.06^{\mathrm{a}}$ \\
Group6 & $46.24 \pm 0.77^{\mathrm{d}}$ & $72.52 \pm 1.14^{\mathrm{c}}$ & $70.22 \pm 0.45^{\mathrm{b}}$ & $17.71 \pm 0.68^{\mathrm{c}}$ & $5.76 \pm 0.61^{\mathrm{b}}$ & $2.06 \pm 0.05^{\mathrm{b}}$ \\
\hline
\end{tabular}

Values are means $\pm \mathrm{SD}, n=10$. Within an array, values without a common superscript significantly differ, $P<0.05$. CAT, catalase; Group 1 and 4 (normal protein diets [NPD]), a normal diet containing $20 \%$ casein or soy protein, respectively; Group 2 and 5 (high protein diets [HPD]), a high protein diet containing $60 \%$ casein or soy protein, respectively; Group 3 and 6 , high protein diets plus $0.06 \mathrm{~g} / \mathrm{kg}$ cysteamine.

\section{Discussion}

With the elevation of living standards, the amount of protein ingested by people has increased and is above actual nutritional requirements. However, whether the high protein intake will cause adverse effects to the healthy population is still controversial. Many findings indicate that high protein intakes (more than $40 \%$ protein level) increase the thermogenic response, which is accompanied by a lower efficiency of food energy utilization, an increase in oxygen consumption, and impaired oxidative phosphorylation capacities (lower adenosine diphosphate oxygen values for nicotinamide adenine dinucleotide-linked substrates in mitochondria) [28-30]. Thus, we assumed that high protein ingestion 
could induce oxidative stress. In the present study, results showed that ingestion of high protein diets caused increments in the levels of oxidative parameters and decrease in antioxidative activity in digestive organs of mice. This imbalance between the production of free radicals and the ability of the organism's natural protective mechanisms is due to excessive oxidation of amino acids.

Oxidative stress is one of the causative factors of many diseases such as atherosclerosis [31]. An imbalance between production of free radicals and antioxidant level leads to oxidative stress, which is obvious from the depressed antioxidant defense system in the HPD groups of our study. Cysteamine acts as an antioxidant for its sulfhydryl in relation to effectively scavenging free radicals (e.g., hydroxyl radical) [32]. Moreover, cysteamine can stimulate GSH synthesis [33]. In the present study, administration of cysteamine to HPD-fed mice prevented the buildup of oxidative stress by restoring normal activities of the enzymatic antioxidant SOD, CAT and GSH-Px and normal levels of the non-enzymatic antioxidant GSH in the digestive organs; the concentrations of these antioxidants were decreased in the HPD-fed mice. The diminished antioxidant defense system in HPD-fed mice leads to damage of the so-called lipid peroxidation system. We observed increased concentration of MDA, indices of lipid peroxidation, and superoxide anion, the precursor of most reactive oxygen species (ROS) and a mediator in oxidative chain reactions, in the peptic of HPD-fed animals. Administration of cysteamine decreased significantly the lipid peroxidation. This suggests that cysteamine played an antioxidant role in oxidative stress induced by the HPDs.

$\mathrm{Na}^{+} \mathrm{K}^{+}$-ATPase, which is a cell membrane protease maintains the electrochemical potential gradient of $\mathrm{Na}+$ and $\mathrm{K}+$ ions in the membranes of cells, and plays an important role in the transport of substances, energy conversion and information transfer [34-36]. The decrease of its activity indicates substances and energy dysmetabolism [37]. In the present study, the activity of $\mathrm{Na}^{+} \mathrm{K}^{+}$-ATPase was markedly lower in mice fed the HPD compared with those fed the NPD, which indicates that oxidative stress induced by the HPD diets impairs biomembrane. Moreover, lesion of biomembrane led to the ion pumping dysfunction of the $\mathrm{Na} / \mathrm{K}$-ATPase, which could increase $\left[\mathrm{Ca}^{2+}\right]$ and open mitochondrial ATP-sensitive $\mathrm{K}$ channel (mitoK $\mathrm{ATP}_{\text {) }}$ ) and further stimulate the production of ROS [37-39].

Dietary-protein origin may influence lipid peroxidations. Chiang and Kimura [40] reported that liver and testis lipid peroxide concentrations are significantly lower in stroke-prone spontaneously hypertensive rats (SHR) fed soybean protein than in those fed casein. In rabbits, the soybean protein diet lowers plasma cholesterol level and causes fewer atherosclerotic lesions compared with rabbits fed the casein diet [41]. Madani et al. [17] reported that concentrations of plasma TBARS were lower in rats fed a soybean protein diet than those in rats fed a casein diet. Aoki et al. [19] demonstrated that soybean protein has antioxidative effects on paraquat-induced oxidative stress in rats. The antioxidative activity of soybean protein can potentially be explained by its amino acid composition or the effects of soybean peptides. L-Arginine is reported to have antioxidative activity [42] and is more abundant in soybean protein than in casein. Suetsuna et al. [43] investigated the antioxidative activity of soybean protein hydrolysate and reported two soybean peptides with strong antioxidative activity. Antioxidative activity of histidine-containing peptides from soybean protein has also been reported [44]. In present study, lower levels of oxidative parameters (MDA and superoxide anion) and higher activities of antioxidant enzymes (SOD, CAT, GSH-Px) in digestive organs were observed in groups fed HPD with soybean protein than those fed HPD with casein. This result may be attributed to the antioxidative activity of soybean protein itself. 
In summary, these findings suggest that oxidative stress may occur in digestive organs of mice because intake of high protein diets caused an imbalance between the production of ROS and the capacity of the antioxidant defense system. However, at the same level, the extent of oxidative stress in mice fed-soybean protein was lower than that in mice fed-casein.

\section{Acknowledgments}

The authors want to thank National Natural Science Foundation of China (NSFC, No.30571347) for the funding.

\section{References}

1. Bankir, L.; Kriz, W. Adaptation of the kidney to protein intake and to urine concentrating activity: similar consequences in health and CRF. Kidney Int. 1995, 47, 7-24.

2. Brändle, E.; Sieberth, H.G.; Hautmann, R.E. Effect of chronic dietary protein intake on the renal function in healthy subjects. Eur. J. Clin. Nutr. 1996, 50, 734-740.

3. Yanagisawa, H.; Wada, O. Effects of dietary protein on eicosanoid production in rat renal tubules. Nephron 1998, 78, 179-186.

4. Chow, W.H.; Gridley, G.; McLaughlin, J.K.; Mandel, J.S.; Wacholder, S.; Blot, W.J.; Niwa, S.; Fraumeni, J.F. Jr. Protein intake and risk of renal cell cancer. J. Natl. Cancer Inst. 1994, 86, 1131-1139.

5. Kitagawa, T.; Owada, M.; Urakami, T.; Yamauchi, K. Increased incidence of non-insulin dependent diabetes mellitus among Japanese schoolchildren correlates with an increased intake of animal protein and fat. Clin. Pediatr. 1998, 37, 111-115.

6. Tsunehara, C.H.; Leonetti, D.L.; Fujimoto, W.Y. Diet of second-generation Japanese-American mean with and without non-insulin-dependent diabetes. Am. J. Clin. Nutr. 1990, 52, 731-738.

7. Vlajinac, H.D.; Marinkovic, J.M.; Ilic, M.D.; Kocev, N.I. Diet and prostate cancer: a case-control study. Eur. J. Cancer 1997, 33, 101-107.

8. Holmes, R.P.; Goodman, H.O.; Hart, L.J.; Assimos, D.G. Relationship of protein intake to urinary oxalate and glycolate excretion. Kidney Int. 1993, 44, 366-372.

9. Price, G.M.; Halliday, D.; Pacy, P.J.; Quevedo, M.R.; Millward, D.J. Nitrogen homeostasis in man: Influence of protein intake on the amplitude of diurnal cycling of body nitrogen. Clin. Sci. 1994, 86, 91-102.

10. Porrata-Maury, C.; Aust, L.; Noack, R.; Eschrich, H. Studies on the postprandial thermogenic action of proteins and protein mixtures in rats. Nahrung 1987, 31, 311-319.

11. Robinson, S.M.; Jaccard, C.; Persaud, C.; Jackson, A.A.; Jequier, E.; Schutz, Y. Protein turnover and thermogenesis in response to high-protein and high-carbohydrate feeding in men. Am. J. Clin. Nutr. 1990, 52, 72-80.

12. Petzke, K.J.; Proll, J. [NAD1] [NADH] redox-state metabolites of freezed-clamped livers of rats fed casein or gelatin diets. J. Nutr. Biochem. 1994, 5, 495-498.

13. Park, M.S.; Kudchodkar, B.J.; Liepa, G.U. Effects of dietary animal and plant proteins on the cholesterol metabolism in immature and mature rats. J. Nutr. 1987, 117, 30-35. 
14. Messina, M. Soy intake and cancer risk: a review of the in vitro and in vivo data. Nutr. Cancer 1994, 21, 113-131.

15. Madani, S.; Lopez, S.; Blond, J.P.; Prost, J.; Belleville, J. Highly purified soybean protein is not hypocholesterolemic in rats but stimulates cholesterol synthesis and excretion and reduces polyunsaturated fatty acid biosynthesis. J. Nutr. 1998, 128, 1084-1091.

16. Choi, Y.S.; Goto, S.; Ikeda, I.; Sugano, M. Interaction of dietary protein, cholesterol and age on lipid metabolism of the rat. Br. J. Nutr. 1989, 61, 531-543.

17. Madani, S.; Prost, J.; Belleville, J. Dietary protein level and origin (casein and highly purified soybean protein) affect hepatic storage, plasma lipid transport, and antioxidative defense status in the rat. Nutrition 2000, 16, 368-375.

18. Kanazawa, T.; Osanak, T.; Zhang, X.S.; Umehara, T.; Yin, X.Z.; Onodera, K.; Oike, Y.; Ohkubo, K. Protective effects of soy protein on the peroxidizability of lipoprotein in cerebrovascular disease. J. Nutr. 1995, 125, 639S-646S.

19. Aoki, H.; Otaka, Y.; Igarashi, K.; Takenaka, A. Soy Protein Reduces Paraquat-Induced Oxidative Stress in Rats. J. Nutr. 2002, 132, 2258-2262.

20. Pick, E. Microassays for superoxide and hydrogen peroxide production and nitroblue tetrazolium reduction using an enzyme immunoassay microplate reader. Methods Enzymol. 1986, 132, 407-421.

21. Ohkawa, H.; Ohishi, N.; Yagi, K. Assay for lipid peroxides in animal tissues by thiobarbituric acid reaction. Anal. Biolchem. 1979, 95, 351-358.

22. Hafeman, D.G.; Sunde, R.A.; Hoekstra, W.G. Effect of dietary selenium on erythrocyte and liver glutathione peroxidase in the rat. J. Nutr. 1974, 104, 580-587.

23. Spitz, D.R.; Oberley, L.W. An assay for superoxide dismutase activity in mammalian tissue homogenates. Anal. Biochem. 1989, 179, 8-18.

24. Moron, M.S.; Depierre, J.W.; Mannervik, B. Levels of glutathione, glutathione reductase and glutathione S-transferase activities in rat lung and liver. Biochim. Biophys. Acta. 1979, 582, 67-78.

25. Reinila, M.; MacDonald, E.; Salem, N.Jr. Linnoila, M.; Trams, E.G. Standardized method for the detemination of human erythroyte membrane adenosine triphosphatases. Anal. Biochem. 1982, 124, 19-26.

26. Aebi, H. Catalase. Bergmeyer, H. U. eds. Methods of Enzymatic Analysis, 2nd ed; Verlag Chemie Weinheim; Germany, 1974, pp. 673-684.

27. Lowry, O.H.; Rosebrough, H.J.; Farr, A.L.; Randall, R.J. Protein measurement with the Folinphenol reagent. J. Biol. Chem. 1951, 193, 265-275.

28. Klein, M.; Hoffmann, L. The effect of the protein level of food on the energy maintenance requirement of growing rats on different feeding regimens. Arch. Tierernahr. 1993, 44, 95-109.

29. Miller, D.S.; Mumford, P. Gluttony. 1. An experimental study of overeating low- or high-protein diets. Am. J. Clin. Nutr. 1967, 20, 1212- 1222.

30. Toyomizu, M.; Tanaka, M.; Kojima, M.; Ishibashi, T. The substrate-specific impairment of oxidative phosphorylation in liver mitochondria from high-protein-fed chickens. Brit. J. Nutr. 1995, 74, 797-806. 
31. Young, I.S.; McEneny, J. Lipoprotein oxidation and atherosclerosis. Biochem. Soc. Trans. 2001, $29,358-362$.

32. Zhu, J.J.; Le, G.W.; Shi, Y.H. Biological function and application of cysteamine. China Feed 2005, 24, 22-23 (in Chinese).

33. Matos, D.G. de; Nogueira, D.; Cortvrindt, R.; Herrera, C.; Adriaenssens, T.; Pasqualini, R.S.; Smitz, J. Capacity of adult and prepubertal mouse oocytes to undergo embryo development in the presence of cysteamine. Mol. Reprod Dev. 2003, 64, 214 -218.

34. Zhao, Sh,M,; He, X.J.; Huang, L.J.; Jin, L. Wang C.B.; Liang, Z.R.; Huang, Y.Y.; Huang, Y.F. Effect of acute hypoxia on SOD, MDA, NO and Na, K-ATPase in rabbits. J. Clin. Exp. Med. 2003, 2, 155-157 (in Chinese).

35. Glitsch, H.G. Electrophysiology of the sodium-potassium-ATPase in cardiac cells. Physiol. Rev. 2001, 81, 1791-1826.

36. Jorgensen, P.L.; Pedersen, P.A. Structure-function relationships of $\mathrm{Na}^{+}, \mathrm{K}^{+}, \mathrm{ATP}$, or $\mathrm{Mg}^{2+}$ binding and energy transduction in Na, K-ATPase. Biochim. Biophys. Acta. 2001, 1505, 57-74.

37. Guo, J.R.; Cui, J.J.; Ding, J.Q.; Ren, L.Y.; Yu, L.T. Effects of propofol on energy metabolism, Na, K-ATPase activity and lipid peroxidation of hippocampus mitochondrial following global ischemia-reperfusion in rats. Chin. J. Clin. Pharmacol. Ther. 2004, 9, 893-896 (in Chinese).

38. He, L.Y.; Huang, C.X. Effects of Dall on ATPase and free radicals metabolism of brain following ischemia-reperfusion in rats. J. Hubei Preclin. Med. 2003, 14, 1-3 (in Chinese).

39. Xie, Z. Molecular mechanisms of Na/K-ATPase-mediated signal transduction. Ann. N.Y. Acad. Sci. 2003, 986, 497-503.

40. Chiang, M.T.; Kimura, S. Effect of dietary protein on the peroxidation of eicosapentaenoic acid in stroke-prone spontaneously hypertensive rats. Int. J. Vitam. Nutr. Res. 1991, 61, 239-243.

41. Bergeron, N.; Jacques, H. Influence of fish protein as compared to casein and soy protein on serum and liver lipids, and serum lipoprotein cholesterol levels in the rabbit. Atherosclerosis 1989, 78, 113-121.

42. Wallner, S.; Hermetter, A.; Mayer, B.; Wascher, T.C. The alpha-amino group of L-arginine mediates its antioxidant effect. Eur. J. Clin. Invest. 2001, 31, 98-102.

43. Suetsuna, K. Separation and identification of peptides derived from soybean protein, and their active oxygen scavenging activity. J. Jpn. Soc. Nutr. Food Sci. 1999, 52, 225-228.

44. Chen, H.-M.; Muramoto, K.; Yamauchi, F.; Fujimoto, K.; Nokihara, K. Antioxidative properties of histidine-containing peptides fragments found in the digests of a soybean protein. J. Agric. Food Chem. 1998, 46, 49-53.

(C) 2008 by MDPI (http://www.mdpi.org). Reproduction is permitted for noncommercial purposes. 